\title{
A Journey of Self-Reflection in Students' Perception of Practice and Roles in the Profession
}

\author{
Remigijus Bubnys (1)
}

Research Institute, Siauliai University, 25 Visinskio Street, 76351 Siauliai, Lithuania; remigijus.bubnys@su.lt; Tel.: +370-673-12930

Received: 7 December 2018; Accepted: 27 December 2018; Published: 2 January 2019

check for updates

\begin{abstract}
The basis of the study is the findings of scientific research dealing with experiential reflections of university students studying in the special education Bachelor degree study program in Lithuania. The special educator is a teacher of children with special educational needs, an educational assistance specialist who is able to recognize, assess, and meet children's special educational needs arising due to disabilities, disorders, or learning difficulties, and to professionally provide special pedagogical assistance in the conditions of inclusive and special education. In order to analyze the experience of prospective special educators who study at the university for four years, first year students were chosen. At the start of their studies at the university, in the first month of their studies, students do their practice in the institutions of the educational system: Pre-school, general, and/or special education institutions. The aim of the practice is to get familiar with the subtleties of the future professional activity. It is maintained that students' initial experience outlived at the start of studies is important and significant for further studies at the university. The article deals with the results of written reflections of students who have returned from practice. The phenomenological hermeneutics method enabled to disclose students' experiences in their practical activities during their observational practice, providing deeper understanding of the study area, as a precondition for reflective learning in further university studies, and by interacting with participants of the (self) education process, the article presents future special educators' practical experiences and perceptions of their roles in the profession. The results disclosed that self-reflection provides students with deeper perception of themselves as people with special educators' needs and problems, personal strengths and competence limitations that enable them to identify sources and means for solving existing and future professional activity problems. It further reveals that cooperation with family members, university teachers, social pedagogues, teachers, children with special educational needs, sharing experiences with student colleagues could lead to greater self-confidence in oneself as a future specialist. Curiosity and personal initiative enabled students to identify positive and difficult moments of the professional activity and future professional role while learning from experience.
\end{abstract}

Keywords: Experience; student; higher education; practice; self-reflection; (self-)educational process; roles in the profession

\section{Introduction}

The goal of education for sustainable development is to develop competencies relevant for professional and social activities and a person's self-expression in the rapidly changing world, distinguishing itself by manifold relationships [1,2]. Sustainable development in education is related to the development of transformational competencies [3,4]. In this respect, a special role falls on higher education institutions educating teachers. One of the essential goals is to ensure that educating teachers, the principles of education for sustainable development, are actually implemented and that future educators acquire such competence that would enable to implement education for 
sustainable development in the teaching/learning process. Among other aims, higher education institutions seek to educate independent students and professionals in their study areas. Successful implementation of this aim requires acknowledgment of the fact that becoming independent primarily relates to development of self-assessment abilities in order to know and reflect on future professional activities [5-10]. The development of latter abilities is possible through continuous communication and cooperation with all participants of the (self)educational process, who take part directly and indirectly in the process of becoming professionals in their study area [11-13]. It is important to help students recognize what they have to know and why. The next step is for them to know how to apply their knowledge in various problem situations in order to broaden their understanding.

In order to ensure high quality (self)education for all members of the society, recognizing and respecting diversity, taking into account every person's individual abilities and their needs, it becomes important to ensure availability and assistance to the persons who are more vulnerable and discriminated due to their particularities and specific needs. In this case, much attention must be paid to persons with special educational needs. Big responsibility in this case falls on the educational assistance specialists-special educators and higher education institutions preparing them. The special educator is a provider of direct assistance to the child who has special educational needs in the general education school and/or specialized special education centres [14].

In Lithuania, special educators are educated at one of the 14 universities, in which the study was conducted, the results of which are presented here [15]. The latter university has implemented the study program Special Education (later, Special Education and Speech Therapy), attributed to education sciences) for more than fifty years. The content of the program is modelled so that it ensures the provision of qualified assistance to pupils of all age groups while solving emerging learning problems: Identifying the principles of curriculum individualization choosing, adapting and implementing appropriate learning strategies, teaching aids and compensatory equipment and providing other learning-related services. The special educator is a teacher of children with special educational needs and a teamwork representative, who is able to communicate and collaborate with teachers, children with special educational needs, their families, and professionals. During studies, implementing the special education and speech therapy study program, new knowledge, learning experiences, and each student's unique path of learning are developed through teacher-student collaboration, involving social partners from educational institutions, and using international experience. Therefore, it is obvious that the efficacy of special pedagogical assistance is determined by the interaction between special educators and other teachers while performing the main function, i.e., implementing key ideas of inclusion and empowerment.

Reflection during studies is especially important in education of future special educators for their inclusive type of work [16-20], when the activities are based on relations between the educational process participants, encountering personal objections, contradictory feelings and emotions, and the like. Special educators who seek humane and stimulating inclusive education will be able to integrate their own experience and theoretical knowledge when they adequately reflect during their study, which is one of the aims required to foster students' ability to reflect on their own experiences [21-23].

Reflective analysis of one's actions with regard to interactions and cooperation between the participants of the education process, taking place at the higher education institution, is a complex teaching/learning process that can be developed both formally and non-formally. While the reflection competency can also be developed in an isolated environment in which students analyze their actions themselves, having dissociated from others, this does not enhance their learning abilities. Communication, cooperation, and feedback from teachers, practice supervisors (mentors), student colleagues, and other stakeholders are all relevant and significant in this process [24-27]. In the presence of cooperation environment, reflection enables the student's professional development at the higher education institution [28-30]. The reflection process is basically a "conversation with oneself": You give questions to yourself, consider solutions, evaluate results and make changes; but in most 
cases, individual reflection begins as cooperation between family members, teachers and students, and practitioners, i.e., as a part of the group work process.

By interacting with others, students are able to understand themselves better as prospective special educators, their needs and problems, personal strengths and competence limitations, and they are also able to identify sources and means for addressing current and future problems of professional activities. This is also grounded by Hilden and Tikkamäki [31] (p. 83) who stated that "When promoting reflection through external dialogue, individuals together try to find something new and surprising - to be touched upon-in open interaction".

Relating with other individuals during the period of reflection enables students to get used to coping with the complexities, challenges and uncertainties which are inherent in personal and professional development, by explicitly or implicitly intervening and using the students' knowledge to facilitate reflection. In addition to relating with the teacher or professional, relating to other students and personal interests are also relevant as they promote reflection processes. Individual analysis of thoughts and feelings, sharing life experiences with other students, as pointed out by Peltier et al. [32], are considered to be the basis for reflection and change. Dialogue between students helps the learner to discover individual meaning of learning.

The objective of this research is a journey of self-reflection in students' perception of practice and roles in the profession by interacting with participants of the (self)educational process.

The research aim is to disclose the experiences and effects of self-reflection on students of special education by interacting with participants of the educational process in order to establish their views and roles in the profession.

\section{Materials and Methods}

\section{Research Methodology}

Sample. The research sample consisted of 71 students, i.e., all first-year students who chose to study special education study program at the university in Lithuania. During studies, students get prepared to educate disabled children, children with special educational needs and other developmental disorders, to professionally provide special educational assistance in the conditions of inclusive and special education, adhere to the principles of tolerance and human values, working in different types of educational institutions, specialist teams, counselling teachers and pupils' parents. After four years of studies, students who have chosen special education studies acquire the educator's qualification.

Written reflections submitted by 65 students were analyzed. The number of reflections analyzed was determined by theoretical saturation $[33,34]$, which came to prominence in the course of data analysis: The text or the content of another artefact used for the qualitative research; for example, a letter, diary, in this particular case, written reflection, in which all elements are repeated up to a specific unit of the analysis, allows further not to analyze the units of the analysis given by other respondents (in this case, written reflections).

On the second week of their studies, right after admission to the university, these students participated in the observational practice. The aim of this practice was to develop students' self-reflection skills and students had to perceive themselves as prospective special educators. Upon completion of this practice, students started writing self-reflection reports. Students were exposed to all necessary conditions to be able to purposefully analyze the experiences gained during the practice and to be able to link them with the context of prospective professional area.

Research Methods. Data collection: Unstructured written reflection. Students had to write reflections in three months. In addition to that, they reflected on experiences gained during the meetings in which the researcher presented indirect type questions. This way, which is quite frequently used in qualitative research [35-37], the students analysed the experience they had outlived during their practical trainings. Students were given open-ended questions, encouraging them to remember 
the experience outlived in practice and describe it in detail as much as possible, distinguishing specific events and describing their performed actions, looking back to their activities and reflecting themselves in various aspects. More detailed instructions were not given, leaving them to decide what was most important, relevant, and significant speaking about themselves and not about expectations of others. Writing of the reflections took them from one to one and a half hours.

In this particular case, reflective writing encompassed the analysis of a wider context of experience and action, meaning, and sense, and was also used as a research strategy for collecting data. According to Moon [38], reflective writing can be undertaken for a number of reasons, such as: the development of theory and adjustment in practical studies, preparation of an action plan, solution of obscurities and search for alternatives, evaluation of personal progress, etc. Written reflection created preconditions for students to analyze the experience outlived during practice, analyzing the experienced events. Based on the advantages and aims of reflective writing explained by scholars [39-42], in this case it was sought to generalize experiences and personal development related to practice performed at the institution. It is important to capture experience and think it over. Students had opportunities to reflect on the process of their learning, i.e., the meta-cognitive process, during acquisition of new experience.

To sum up, it should be stated that the choice of the method was based on the following essential approaches: Writing is inherently related to reflection, when questions and thoughts about the investigated phenomenon are written down creating the possibility to go back and reflect; the aim of writing is to empower us to see what we had not seen before so that the phenomenon is shown in a new way; writing can be compared with "falling forward-into the dark" with the aim of contacting what is not yet known, what was experienced as a whole; writing reveals richness of the phenomena in the outlived experience; writing is both a research process and product; writing is for investigating phenomena in the experienced world and for passing on the results of our investigation to others.

Data analysis: the phenomenological hermeneutics method. The method of phenomenological hermeneutics was employed, analyzing the text by phases, moving from the whole to the parts and back, and from understanding to explanation and back [43]: (1) Naive reading; (2) structural analyses, formulating themes; (3) full understanding, which contains generalization and reflection on the themes with regard to the research matter and research context; and (4) formulation of the results, presenting them in simple language and keeping it close to what was experienced.

\section{Results}

Having analyzed the written reflections on the question, "What people helped to understand subtleties of practice and what are one's specialist's role?" The phenomenological hermeneutics method comprising of seven dimensions and 24 themes was used to diagnose the answer.

\subsection{The First Dimension}

Understanding of practice subtleties in relating with family members reveals family members' support for future special educators, who are getting familiar with peculiarities of the chosen specialty during their observational practice (see Table 1).

While solving problems, which they encountered in practice, students received information, support and assistance from their family members. Students mostly lacked information and skills of communication with children and possibilities of providing assistance for them. Reflections revealed that mothers helped students most in comparison with other family members. Based on her teaching experience, the mother "...much helped to understand how to communicate with children [...] encouraged, morally supported..." Mother's psychological support, consolation, and encouragement motivated students to go deep into the study area, increased their self-confidence, foreseeing their possible actions with children in the future: “... because I was very afraid to do practice [...] my mother calmed me down [...] said what I can expect, what awaits me [...]". Different special educators' activity aspects were analyzed; ways of behavior and assistance were studied and children's disabilities were discussed, considering the type of the disability. 
Table 1. Understanding of Practice Subtleties in Relating with Family Members.

\begin{tabular}{|c|c|c|}
\hline Theme & Subtheme 2 & Subtheme 1 \\
\hline \multirow{6}{*}{$\begin{array}{l}\text { Explanation of behavior and ways } \\
\text { of assistance for children }\end{array}$} & \multirow{3}{*}{$\begin{array}{l}\text { Explanation of children's behavior } \\
\text { and ways of communicating } \\
\text { with them. }\end{array}$} & $\begin{array}{l}\text { Explanation of children's behavior } \\
\text { emphasizing the importance } \\
\text { of work }\end{array}$ \\
\hline & & $\begin{array}{l}\text { Explanation of communication } \\
\text { with children by encouragement } \\
\text { and moral support }\end{array}$ \\
\hline & & $\begin{array}{l}\text { Explanation of main subtleties of } \\
\text { practice and ways of behaving } \\
\text { with children }\end{array}$ \\
\hline & $\begin{array}{l}\text { Discussion of tactics of behavior } \\
\text { with children }\end{array}$ & $\begin{array}{l}\text { Assistance, foreseeing ways of } \\
\text { behavior with children in various } \\
\text { situations }\end{array}$ \\
\hline & \multirow{2}{*}{$\begin{array}{l}\text { Emphasis on ways of assistance } \\
\text { for children }\end{array}$} & $\begin{array}{l}\text { Emphasis on ways of necessary } \\
\text { assistance for children by } \\
\text { encouragement }\end{array}$ \\
\hline & & $\begin{array}{l}\text { Foreseeing of ways of assistance } \\
\text { for children by discussing }\end{array}$ \\
\hline \multirow{2}{*}{ Promotion of professional resolve } & \multirow{2}{*}{$\begin{array}{l}\text { Promotion of conviction to work } \\
\text { in one's profession }\end{array}$} & $\begin{array}{l}\text { Promotion seeking to make sure } \\
\text { that the choice of the profession is } \\
\text { right by observation }\end{array}$ \\
\hline & & $\begin{array}{l}\text { Emphasis on the purpose of } \\
\text { practice, encouraging to assess } \\
\text { one's choice to study }\end{array}$ \\
\hline Emphasis on professional traits & $\begin{array}{l}\text { Emphasis on responsibility and } \\
\text { dutifulness }\end{array}$ & $\begin{array}{l}\text { Importance of responsibility and } \\
\text { dutifulness, implementing } \\
\text { professional roles }\end{array}$ \\
\hline $\begin{array}{l}\text { Promotion of investigative } \\
\text { activities }\end{array}$ & $\begin{array}{l}\text { Encouragement to investigate } \\
\text { activities }\end{array}$ & $\begin{array}{l}\text { Encouragement to investigate in } \\
\text { order to understand }\end{array}$ \\
\hline \multirow{2}{*}{$\begin{array}{l}\text { Foreseeing difficulties in } \\
\text { professional activities }\end{array}$} & $\begin{array}{l}\text { Perception of difficulties in } \\
\text { professional activities }\end{array}$ & $\begin{array}{l}\text { Discussion of future professional } \\
\text { activities, foreseeing possible } \\
\text { difficulties }\end{array}$ \\
\hline & $\begin{array}{l}\text { Provision of information about } \\
\text { complicated situations in practice }\end{array}$ & $\begin{array}{l}\text { Informing about troubles working } \\
\text { with the disabled }\end{array}$ \\
\hline
\end{tabular}

Mothers were also the ones who mostly encouraged students to evaluate their choice of studies by making sure that students were suited for the chosen profession: "...helped to understand the importance of practice, so that I could find out if I can work, if I am not afraid of such work and whether I entered where I wanted ..." They discussed personality traits required for the special educator, the most important being responsibility and dutifulness. Family members deliberately hoped that discussions about future professional activities would affect students' actions and attitude towards science, motivate them for responsible and purposeful future activities, and encourage them to embrace (self)development of the personality traits needed for this work.

A mother encouraged her ward to perceive professional role through investigation of activities: "... she would always say that it was necessary to investigate everything, so that you could understand whether you like it..." Investigation of performed activities helped to better understand their professional roles: "... helped me to imagine myself as a special educator..."; abilities of investigative activities and learning to learn were also developed. Based on personal experience, students' parents would consider future complex professional activity areas while working with disabled people. 


\subsection{The Second Dimension}

Cognition of practice subtleties in relating with special educators and teachers reveals special educators' and subject teachers' / form tutors' assistance for trainees (see Table 2).

Table 2. Cognition of Practice Subtleties through Relating with Special Educators and Teachers.

\begin{tabular}{|c|c|c|}
\hline Theme & Subtheme 2 & Subtheme 1 \\
\hline \multirow{3}{*}{$\begin{array}{l}\text { Disclosure of children's personal } \\
\text { characteristic }\end{array}$} & \multirow{3}{*}{$\begin{array}{l}\text { Informing about children's } \\
\text { personal traits }\end{array}$} & $\begin{array}{l}\text { Assistance with recognizing } \\
\text { children's needs }\end{array}$ \\
\hline & & Identification of children's needs \\
\hline & & $\begin{array}{l}\text { Familiarization with children's } \\
\text { personal and family peculiarities }\end{array}$ \\
\hline \multirow{2}{*}{$\begin{array}{l}\text { Provision of knowledge about } \\
\text { communication with children }\end{array}$} & $\begin{array}{l}\text { Assistance in communication with } \\
\text { children }\end{array}$ & $\begin{array}{l}\text { Informing about individual } \\
\text { communication with children }\end{array}$ \\
\hline & $\begin{array}{l}\text { Explanation of individual } \\
\text { communication with children }\end{array}$ & $\begin{array}{l}\text { Explanation of peculiarities of } \\
\text { individual approach to each child }\end{array}$ \\
\hline \multirow{4}{*}{$\begin{array}{l}\text { Explanation of organization of } \\
\text { activities with children }\end{array}$} & $\begin{array}{l}\text { Presentation of specificity of the } \\
\text { activity according to children's } \\
\text { needs }\end{array}$ & $\begin{array}{l}\text { Explanation of peculiarities of } \\
\text { special needs of children and } \\
\text { specificity of work with them }\end{array}$ \\
\hline & $\begin{array}{l}\text { Foreseeing behavior strategies in } \\
\text { teaching }\end{array}$ & $\begin{array}{l}\text { Explanation of behavior with } \\
\text { disabled children in the teaching } \\
\text { process }\end{array}$ \\
\hline & $\begin{array}{l}\text { Explanation of requirements for } \\
\text { children according to their needs }\end{array}$ & $\begin{array}{l}\text { Explanation of peculiarities of } \\
\text { communication with children: } \\
\text { their needs and requirements for } \\
\text { them }\end{array}$ \\
\hline & $\begin{array}{l}\text { Transfer of experience, managing } \\
\text { situations in communication with } \\
\text { children }\end{array}$ & $\begin{array}{l}\text { Transfer of experience of "taming" } \\
\text { difficult-to-communicate children } \\
\text { through observation }\end{array}$ \\
\hline \multirow{3}{*}{$\begin{array}{l}\text { Familiarization with children's } \\
\text { educational process }\end{array}$} & $\begin{array}{l}\text { Sharing experiences about } \\
\text { children's involvement in learning }\end{array}$ & $\begin{array}{l}\text { Advice on how to arouse } \\
\text { children's interest in the subject, } \\
\text { allowing to give lessons }\end{array}$ \\
\hline & $\begin{array}{l}\text { Informing about the parameters of } \\
\text { the educational process }\end{array}$ & $\begin{array}{l}\text { Familiarization with curricula, } \\
\text { children and school specificity }\end{array}$ \\
\hline & $\begin{array}{l}\text { Acquisition of knowledge about } \\
\text { differentiation of individual tasks }\end{array}$ & $\begin{array}{l}\text { Finding out about peculiarities of } \\
\text { tasking for children and } \\
\text { communication with children } \\
\text { through observed activities }\end{array}$ \\
\hline \multirow{2}{*}{$\begin{array}{l}\text { Provision of information about } \\
\text { specificity of disability }\end{array}$} & $\begin{array}{l}\text { Provision of knowledge about } \\
\text { children's diseases }\end{array}$ & $\begin{array}{l}\text { Provision of information about } \\
\text { diseases inherent in children }\end{array}$ \\
\hline & $\begin{array}{l}\text { Provision of knowledge about } \\
\text { children's faculties depending on } \\
\text { the disability }\end{array}$ & $\begin{array}{l}\text { Provision of information about } \\
\text { children's faculties, disabilities }\end{array}$ \\
\hline \multirow{3}{*}{$\begin{array}{l}\text { Disclosure specificity of the } \\
\text { chosen specialty }\end{array}$} & $\begin{array}{l}\text { Presentation of the actual practice } \\
\text { situation }\end{array}$ & $\begin{array}{l}\text { Distinguishing of advantages and } \\
\text { disadvantages of the chosen } \\
\text { specialty }\end{array}$ \\
\hline & $\begin{array}{l}\text { Deepening of understanding } \\
\text { about the type of work }\end{array}$ & $\begin{array}{l}\text { Development of understanding } \\
\text { about difficulty and responsibility } \\
\text { of work }\end{array}$ \\
\hline & $\begin{array}{l}\text { Emphasis on moments of the } \\
\text { activity }\end{array}$ & $\begin{array}{l}\text { Familiarization with the specificity } \\
\text { of work, advising on the future } \\
\text { activity }\end{array}$ \\
\hline
\end{tabular}


Table 2. Cont.

\begin{tabular}{lll}
\hline \multicolumn{1}{c}{ Theme } & \multicolumn{1}{c}{ Subtheme 2 } & \multicolumn{1}{c}{ Subtheme 1 } \\
\hline \multirow{3}{*}{$\begin{array}{l}\text { Information about children's } \\
\text { self-feeling and problems }\end{array}$} & $\begin{array}{l}\text { Deepening of understanding of } \\
\text { children's feelings }\end{array}$ & $\begin{array}{l}\text { Explanation of children's feelings } \\
\text { and self-feeling }\end{array}$ \\
\cline { 2 - 3 } & Discussion of children's problems & $\begin{array}{l}\text { Familiarization with children's } \\
\text { learning difficulties }\end{array}$ \\
\hline \multirow{2}{*}{$\begin{array}{l}\text { Complexity of performance of the } \\
\text { teacher's professional role }\end{array}$} & $\begin{array}{l}\text { Foreseeing of possible mistakes in } \\
\text { practice }\end{array}$ & $\begin{array}{l}\text { Explanation of possible mistakes } \\
\text { in the trainee's activity }\end{array}$ \\
\cline { 2 - 3 } & $\begin{array}{l}\text { Performance of the teacher's role } \\
\text { environment }\end{array}$ & $\begin{array}{l}\text { The benefit of practice tasks, } \\
\text { perceiving one's professional role }\end{array}$ \\
\cline { 2 - 3 } & $\begin{array}{l}\text { Plugging in the performance of } \\
\text { the teacher's role in practice }\end{array}$ & $\begin{array}{l}\text { Teacher practitioners' assistance } \\
\text { perceiving positive and difficult } \\
\text { moments of the teacher's role }\end{array}$ \\
\hline \multirow{3}{*}{$\begin{array}{l}\text { Promotion of personal motivation } \\
\text { for activities }\end{array}$} & $\begin{array}{l}\text { Promotion of plugging in the } \\
\text { practical activity context }\end{array}$ & $\begin{array}{l}\text { Encouragement to communicate } \\
\text { in order to get to know the } \\
\text { complexity of work }\end{array}$ \\
\cline { 2 - 3 } & $\begin{array}{l}\text { Promotion of involvement in the } \\
\text { activity with children }\end{array}$ & $\begin{array}{l}\text { Encouragement to observe and } \\
\text { participate in children's activities }\end{array}$ \\
\hline
\end{tabular}

During practice, students were made to familiarize with their future profession by special educators and subject teachers, who discussed ways of dealing with or assisting children, provided concrete advice and enabled them to learn from their mistakes. Information provided by special educators and teachers about communication with children helped students to understand the importance of individual communication with each child: “ . . explained how to approach each child, what were the child's usual moods. I understood that each child was different, communication with every child was individual..." Teachers helped students to understand that the peculiarity of communicating with children depends on the type of the child's disability.

Special educators provided information on different type of disabilities in order to help students understand what methods to use to arouse each child's interest, stating that the proper way of correcting behaviors should be applied to achieve adequate results and behavioral changes: " ... explained how a healthy person should behave with the disabled. Not only with children but in general with all people. How they should be taught, interested, disciplined..." By so doing, teachers created avenues for students to involve themselves in activities and try out the advice in practice. Teachers also provided information for students about different educational process parameters: specificity of the school, curricula, children's disabilities, fatigue manifestations, etc.

Students reflect that teachers' explanations about diseases were the most useful: "... allowed to approach children, play with them, help to draw, mould and dress. Told about children's diseases: disorders, what was characteristic for them..." Personal involvement in activities enabled students to analyze their actions in action and learn from their experiences.

Consistency and coherence of personal-internal factors (expectations, needs, feelings, personality traits, interests, etc.) and environmental-external factors (organizational culture and microclimate, customers (children), etc.) create a sense of comfort and help students to grow as personalities and professionals during their practical activities. Mutual support and open relations between the student and practice supervisor are the main prerequisite for constructive reflection and self-reflection [44]. Teachers' personal approach and assessment helped students to better understand children's learning difficulties and experience feelings in various educational process situations. Seeking to avoid mistakes during practice, teachers familiarized students with trainees' most common mistakes. 


\subsection{The Third Dimension}

Understanding how to practice subtleties through Relating with children reflects the peculiarities of perceiving one's role as a specialist's role and in understanding practice subtleties in relations with handling of children (see Table 3).

Table 3. Understanding How to Practice Subtleties through Relating with Children.

\begin{tabular}{|c|c|c|}
\hline Theme & Subtheme 2 & Subtheme 1 \\
\hline \multirow{6}{*}{ Children's indirect "assistance" } & Knowledge of future work & $\begin{array}{l}\text { Experiencing of failures through } \\
\text { performed work }\end{array}$ \\
\hline & $\begin{array}{l}\text { Perception of preconditions for } \\
\text { assistance for children }\end{array}$ & $\begin{array}{l}\text { Perception of importance of } \\
\text { children's cognition and provision } \\
\text { of assistance for them }\end{array}$ \\
\hline & $\begin{array}{l}\text { Emotional-psychological } \\
\text { entrenchment in the profession }\end{array}$ & $\begin{array}{l}\text { Self-entrenchment in the } \\
\text { profession due to children's } \\
\text { attachment }\end{array}$ \\
\hline & \multirow{3}{*}{ Learning to treat children } & $\begin{array}{l}\text { Understanding of the ways of } \\
\text { acting with children in a particular } \\
\text { situation }\end{array}$ \\
\hline & & $\begin{array}{l}\text { The possibility of implementing } \\
\text { practice roles }\end{array}$ \\
\hline & & $\begin{array}{l}\text { Acquisition of skills of } \\
\text { communication with children }\end{array}$ \\
\hline
\end{tabular}

Students understood the subtleties of practice and their roles as specialists' roles while directly communicating with children: “... communication [...] showed me subtleties of that work. Their presence nearby, talks with them were an interesting experience and made it possible to understand how to communicate with such people..." Experiencing failures and following the very children's advice extended trainees' knowledge of their future work. Successful child-student communication was the strongest argument that the student suitably chose as the high point of his/her profession.

\subsection{The Fourth Dimension}

Cognition of practice subtleties through relating with university teachers reveals teachers' impact on students' practical learning processes, which familiarizes the students with subtleties of their chosen specialties and with the peculiarities of their professional roles (see Table 4).

Table 4. Cognition of Practice Subtleties Knowledge of Their Future Work.

\begin{tabular}{lll}
\hline \multicolumn{1}{c}{ Theme } & \multicolumn{1}{c}{ Subtheme 2 } & \multicolumn{1}{c}{ Subtheme 1 } \\
\hline Evaluation of personal readiness & $\begin{array}{l}\text { Promotion of evaluation of } \\
\text { readiness to work in the chosen } \\
\text { profession }\end{array}$ & $\begin{array}{l}\text { Assistance evaluating one's } \\
\text { readiness to become a special } \\
\text { educator }\end{array}$ \\
\hline $\begin{array}{l}\text { Reflection on the practical activity } \\
\text { by providing feedback }\end{array}$ & Focus on key moments of practice & $\begin{array}{l}\text { Promotion to notice essential } \\
\text { moments of activities in practice }\end{array}$ \\
\cline { 2 - 3 } & Reflection on practice & Sharing impressions after practice \\
\hline
\end{tabular}

University teachers were not active participants of students' observational practice. Consequently, reflections captured their poor contributions by helping students to perceive the study area: "... advised to look at everything more carefully, whether we really entered where we fitted, whether we would be able to do this work..." Teachers were more active when students returned from practice, sharing 
impressions, reflecting on what was experienced and lived during practice, and how the attitude to the future profession was changing. Seibert and Daudelin [45], analyzing the importance of different environmental factors for assuring reflection and reflective teaching and learning at the higher education institution, agree that the university teacher's role in this process is one of the essential determinants. Research results demonstrate that reflection takes place more rapidly through individual and group activities if it is run by a skilled person.

\subsection{The Content of the Fifth Dimension}

Sharing experiences with friends/colleagues discloses a deeper understanding of the subtleties of practice and one's role as a specialist's role in relating with friends and colleagues (see Table 5).

Table 5. Cognition of Practice Subtleties through Relating with Friends/Colleagues.

\begin{tabular}{lll}
\hline \multicolumn{1}{c}{ Theme } & \multicolumn{1}{c}{ Subtheme 2 } & \multicolumn{1}{c}{ Subtheme 1 } \\
\hline $\begin{array}{l}\text { Discussion on performance of the } \\
\text { practical activity }\end{array}$ & $\begin{array}{l}\text { Presentation of possibilities and } \\
\text { limitations in practice }\end{array}$ & $\begin{array}{l}\text { Explanation of peculiarities of } \\
\text { approaching children and } \\
\text { providing assistance for them }\end{array}$ \\
\cline { 2 - 3 } & $\begin{array}{l}\text { Discussion on activity aims in } \\
\text { practice }\end{array}$ & $\begin{array}{l}\text { Finding out and sharing } \\
\text { impressions, better understanding } \\
\text { one's further activities }\end{array}$ \\
\hline Provision of moral support & $\begin{array}{l}\text { Moral support, remaining to study } \\
\text { the profession }\end{array}$ & Encouragement not to quit studies \\
\hline \multirow{2}{*}{$\begin{array}{l}\text { Cooperation through sharing } \\
\text { personal experience }\end{array}$} & $\begin{array}{l}\text { Going deep into practice while } \\
\text { discussing }\end{array}$ & $\begin{array}{l}\text { Recognition of details while } \\
\text { discussing about practice }\end{array}$ \\
\cline { 2 - 3 } & $\begin{array}{l}\text { Promotion of imagination, helping } \\
\text { to go deep into the role of practice }\end{array}$ & $\begin{array}{l}\text { Sharing previously gained } \\
\text { experience during practice }\end{array}$ \\
\hline
\end{tabular}

Due to teachers' limitations not all students had the opportunity to directly interact with the children and to acquire knowledge in the behavior peculiarities of children with special needs. In such cases, students shared acquired experiences with other students "... we found out with group mates, shared impressions and then it was already much clearer what I had to do...", enabling them to plan their further activities with children and better understand aims of their activity.

Students' support was particularly important for those students who hesitated in making up their minds to be special educators. Friends “... encouraged, said, just don't even think about quitting these studies..." Friends' moral support and encouragement prevailed upon several colleagues preventing them from making spontaneous decisions to quit their studies. Senior students who had already completed this practice also helped students to solve practice related problems and to acquire more knowledge and experience.

\subsection{The Sixth Dimension}

Formation of the personal conception reflects the independent formation of students' personal conception about subtleties of practice and their professional roles during practice (see Table 6). 
Table 6. Formation of the Personal Conception.

\begin{tabular}{|c|c|c|}
\hline Theme & Subtheme 2 & Subtheme 1 \\
\hline \multirow{9}{*}{$\begin{array}{l}\text { Assessment of the } \\
\text { practical activity }\end{array}$} & $\begin{array}{l}\text { Identification of difficulties in } \\
\text { professional activities }\end{array}$ & $\begin{array}{l}\text { Foreseeing the course of work and } \\
\text { possible difficulties through the observed } \\
\text { activity }\end{array}$ \\
\hline & \multirow{4}{*}{$\begin{array}{l}\text { Cognition of practical reality } \\
\text { through observation }\end{array}$} & $\begin{array}{l}\text { Cognition of one's future work by } \\
\text { observation }\end{array}$ \\
\hline & & $\begin{array}{l}\text { Understanding of children's behaviour } \\
\text { and communication with them in the } \\
\text { educational process }\end{array}$ \\
\hline & & $\begin{array}{l}\text { Understanding of tactics of work and } \\
\text { behaviour with children }\end{array}$ \\
\hline & & $\begin{array}{l}\text { Understanding of one's role observing } \\
\text { special educators' activities }\end{array}$ \\
\hline & $\begin{array}{l}\text { Independent communication with } \\
\text { children }\end{array}$ & $\begin{array}{l}\text { Understanding of ways of } \\
\text { communicating with children }\end{array}$ \\
\hline & $\begin{array}{l}\text { Systemization of information in } \\
\text { practice }\end{array}$ & $\begin{array}{l}\text { Observation of children and analysis by } \\
\text { accumulating and recording information. }\end{array}$ \\
\hline & \multirow{2}{*}{$\begin{array}{l}\text { Cognition of practical reality } \\
\text { implementing teaching }\end{array}$} & $\begin{array}{l}\text { Perception of the teacher's role through } \\
\text { activity performance }\end{array}$ \\
\hline & & $\begin{array}{l}\text { Solution of problems encountered by } \\
\text { children from their given lessons }\end{array}$ \\
\hline \multirow{9}{*}{ Professional development } & \multirow{2}{*}{ Curiosity for practice } & $\begin{array}{l}\text { Demonstration of pro activeness to get to } \\
\text { know the specialty. }\end{array}$ \\
\hline & & $\begin{array}{l}\text { Activeness and personal initiative as a } \\
\text { possibility to learn }\end{array}$ \\
\hline & $\begin{array}{l}\text { Targeted simulation of } \\
\text { experienced practitioners' activity }\end{array}$ & $\begin{array}{l}\text { Understanding of work by observing the } \\
\text { teacher's activities and behaviour }\end{array}$ \\
\hline & \multirow[b]{2}{*}{ Self-studying } & Individual striving to understand \\
\hline & & $\begin{array}{l}\text { Search for information about children } \\
\text { with special needs }\end{array}$ \\
\hline & \multirow{2}{*}{$\begin{array}{l}\text { Deepening the understanding of } \\
\text { children's needs }\end{array}$} & $\begin{array}{l}\text { Efforts to take interest in and understand } \\
\text { children's needs }\end{array}$ \\
\hline & & $\begin{array}{l}\text { Assistance for children, getting familiar } \\
\text { with their diseases and needs }\end{array}$ \\
\hline & $\begin{array}{l}\text { Solution of problems, } \\
\text { implemented by practitioners }\end{array}$ & $\begin{array}{l}\text { Observation of behaviour with children } \\
\text { and solved problems }\end{array}$ \\
\hline & $\begin{array}{l}\text { Methodological educational } \\
\text { experience }\end{array}$ & Preparation of educational material \\
\hline Professional socialization & $\begin{array}{l}\text { Identification of oneself with the } \\
\text { practical activity }\end{array}$ & $\begin{array}{l}\text { Involvement in pupils' and teachers' } \\
\text { work, perceiving the aims and tasks of } \\
\text { practice }\end{array}$ \\
\hline
\end{tabular}

Cognition of specificities of the professional activity and professional role by observing special educators' activities was the main aim of students' practice. To achieve this, students had to be active participants in this process. Observation was one of the main sources for getting information. When students did not receive help from teachers and practitioners, they themselves had to actively participate in the observation process in order to better understand their study area: "... I had to find out how to communicate with children myself..." Students spent most of their practice time observing and analyzing children's behaviors: "...I was trying to accumulate as much information as possible. 
Most of the time I was watching and recording useful information for myself..." Those students who had the possibility to get directly involved in the teaching process felt that they needed a lot of courage, specialty knowledge and skills for assisting children, and solving children's problems: “...giving the lesson, I felt that I lacked knowledge, courage to give a lesson in a good way...".

During practice, students realized that in order to make practice meaningful, they needed willingness to engage in activities and to be actively communicating with both children and teachers. Students were trying to understand and take over special educators' methodological experience individually: Mainly studying literature on children with special educational needs. Trainees realized that self-studying had changed their conception and knowledge about disabled children: "... when I now compare the knowledge I had before practice and now, it's just not comparable, I feel that I know a lot..." Personal interest extended knowledge about children's needs, diseases, and peculiarities of preparing methodical materials for work with children. Teachers' implemented solutions to problems helped students to understand how children's needs could be met.

\subsection{The Seventh Dimension}

The lack of assistance- "nobody helped"—reflects absence of assistance and the lack of personal motivation, thereby forming the conception of one lacking adequate support and having difficulties in pursuing a future professional role and acquiring new experience for future professional activities.

Some of the students failed to understand their professional roles and the possibilities, which are available to them in their professional activities due to the absence of teachers' social-pedagogical competencies: "... I almost did not see my specialty work ...", "... there were no direct explanations in schools. It seemed as if you were not there at all ...", "... it seems that I am not noticed ..." Students were left unnoticed in practice places or individual teachers' behavior towards them was hostile and ignoring. Individual teachers did not motivate students to take interest in their profession by encouraging them to change their choices and making inadequate assessments of their profession: "... their advice was as follows: hard work, you will not find a job upon graduation. During the lessons, I was not allowed to do anything ...". Often, students lacked educational-counselling assistance about peculiarities and behavior possibilities of children with various disabilities. Absence of such assistance resulted in some students' personal loss of interest to deepen their knowledge and named practice as having a good time: “... I treat these three weeks as vacation, because I did not receive help in understanding the subtleties of this practice ...". The lack of feedback after practice does not create possibilities for students to relate practical knowledge gained while working with children to theoretical knowledge, which they will acquire at the university. This is very important, seeking understanding of the effective and in-depth learning process.

\section{Discussion}

Analyzing the peculiarities of future teachers' education, scholars [46-48] often emphasize that cooperative environment and student support ensure a more successful adaptation to the profession and help to avoid problems encountering the reality in practice. The analysis of the data obtained during the research clearly highlighted not only the level of relationships between the participants of education processes, based on close relations, but also other areas of the professional activity and their content relevant to the student during his/her studies (see Figure 1). 


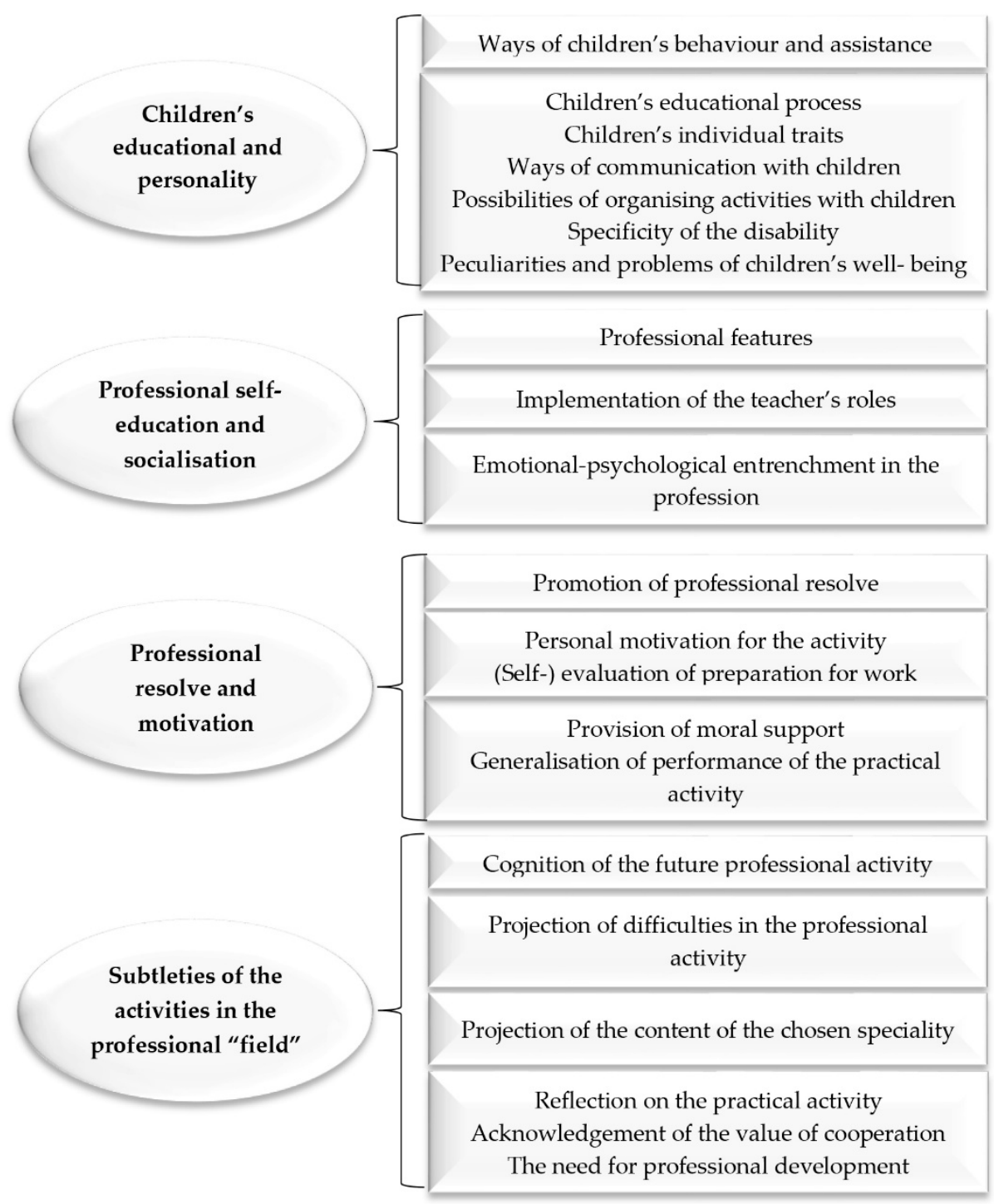

Figure 1. Areas and sources of cognition of professional activity subtleties.

During practice, four essential professional activity areas were relevant for students: Areas related to cognition of the child as a subject of the educational process, personal professional self-education and socialization possibilities, resolve and motivation to study, and professional "field" subtleties. Teachers who already had pedagogical experience in the places of practice were the most active participants and information providers in the process of children's education and personal characteristics. Family members and activities with children also helped to get a better understanding and knowledge of this area. The number of distinguished themes proves that this area was the most important and significant for students. It is evident and natural that the area of cognition of the professional "field" subtleties was not less important. Difficulties in promoting research activities were emphasized by family members and working teachers, while feedback in assisting to evaluate practical activities was accentuated by university teachers.

Entrenchment in the profession both emotionally and psychologically was determined by relationships with children and colleague students. Future special educators had possibilities to evaluate their professional choice and suitability for the profession in the relation with colleague students and on their personal initiative. Reflecting on the performed actions, university teachers and family members, as the main participants of this process, helped to evaluate personal preparation for further study activities. It is often emphasized that prospective specialists' practical training is 
significantly influenced by cooperation between the university teacher (tutor), mentor in the place of practice and student [49-51], which helps to better understand and know the professional field. The data of the conducted research disclosed that, during their practice, students had received the best knowledge of the subtleties of practice and the perception of their role in the profession from family members. This enables to assume that the influence of the family in the process of education is often devalued, although this significantly contributes to the wider extension of knowledge in one's field and more successful formation of the professional identity. General discussion of practice problems with family members, psychological support, promotion of professional resolve, and investigative activities helped students to adapt more successfully to practice places, avoid unpleasant emotions, and negative experiences. Cooperation with family members through sharing experiences led to greater self-confidence of students as future specialists and enhanced motivation to go deep into their study area.

Information provided by special educators and teachers and meaningful cooperation at school created situations that warranted the students to go deep into the study area and enabled them to perceive strategies of communication with children, and to evaluate their roles as future specialists with personality traits that are needed to work with children. They also learnt to understand the specificity of organization of teaching and learning activities, and how to apply concrete working methods. Sharing of professional experience broadened the understanding of the ways of children's involvement in learning, situation management and task differentiation. Conditions created for students to personally involve themselves in concrete activities helped them to understand positive and difficult moments of implementing their future professional roles by learning from experience. Scholars notice that absence of external assistance during practice often causes many social, psychological and other problems [52-57]. Quite often these causes become the reason for termination of studies; therefore, practice mentors' and other teachers' assistance namely during observational practice was particularly important and necessary.

Subtleties of the future specialty unfolded through relations with children with special educational needs: Knowledge of children, understanding of ways of acting with children in a concrete situation, acquisition of communication skills in individual communication, children's attachment and provision of assistance for them were the main factors that determined better professional roles and emotional-psychological entrenchment in the profession of the students as prospective special educators.

Student colleagues' moral support was particularly needed for students who were still in doubt of their choice. Discussion of problems and personal experiences through students' cooperation helped to prevent distanced students from making spontaneous decision to quit their studies. Curiosity and personal initiative during practice enabled students to identify difficulties of their professional activities, also is the issue of independently communicating with children, and systematizing received information. The efficacy of reflective learning is determined not only by the relationship between the university teachers, teachers of the institution and students but also by the relationship between the very learners-practitioners. Cooperation between the latter in the reflective learning process is emphasized by Fisher and Somerton [21] and Dempsey et al. [58], who state that sharing ideas and attitudes with other people who outlived similar experiences is the basis of reflection. Student-student communication facilitates learning and application of existing knowledge. Students, purposefully simulating experienced teachers' activities, developed professionally, took over the methodological experience of education, deepened their understanding about children's special educational needs, and improved their skills of behavior with children and tactics of solving problems.

Analysing the features of manifestation of the teacher education process, it is emphasized that while learning there must be an environment ensuring the learner's autonomy and independence, clear system of incentives and activity priorities, effective feedback, and comprehensive communication and cooperation possibilities for the participants of the educational process [59-61]. One of the ways in which the administration of the higher education institution can facilitate effective relationships is 
simulation of reflective practices [32]. Teachers of the higher education institution (tutors), practice supervisors in schools (mentors) should create conditions for students to see and hear them reflecting in the classroom, practice places and individual meetings. Since reflection is often a personal process, its simulation requires willingness and abilities of the teacher and practitioner who is already working at school to unfold.

Based on the obtained results, it should be recommended that, considering the aims of the first—observational—students' practice, the content of organization of studies should be adjusted: The first week before the observational practice should be dedicated not to studying separate subjects, but to cognitive-practical sessions, providing the basics of application of self-reflection in practice. It is recommended that the teachers who are responsible for practical studies should provide information to practitioners about the problems faced by students, necessary theoretical and methodological information about reflection as a reflective learning tool and its application possibilities during practice in the interaction with the trainee. This can be implemented by attending a concrete educational institution during the student's practice. It is recommended to develop didactic mentoring competencies of practitioners who supervise the student's practice, applying various possible teaching/learning forms. It is recommended to systematically plan and arrange meetings of working specialists and students at least once a month before the beginning of the study practice, through cooperation to find out and discover a general understanding of the aims and nature of the foreseen practice, combining students' and practitioners' expectations, needs and possibilities.

\section{Conclusions}

The interaction of the participants of the educational process and cooperation at the higher education institution help to ensure students' more successful adaptation in the teaching/learning process, perceiving their as future specialists' professional roles and subtleties of future activities. The mutual assistance process enables to create the environment empowering the improvement of reflection abilities that are needed when students become experienced professionals in their professional field. The research results highlighted the obvious need to link theoretical and practical knowledge during studies, where the learner's experience and its analysis become the main source of teaching/learning. The main goal the students and their supervisors at the university and in the place of practice should seek is the transfer of experience and assistance, familiarizing with the peculiarities of the future profession by helping to apply the acquired theoretical knowledge in practice. Every activity during practice should promote the student's further actions while learning, i.e., promote the search for answers to questions that the student failed to answer during the practice.

It is advisable to create support groups, using supervision elements, analyzing problems arising in the relationships with the trainee and projecting possible solutions of these problems. The same idea of support groups can be also transferred to the university environment by developing an optional module of the study subject, which could include the organization of student support groups before and after practice.

The limitation of the conducted research is that the results are presented analyzing students' experience after their first practice during studies. It would be relevant and significant to analyze and explore employing different research strategies, such as observation, action research, etc. in order to reveal the future special educator's professional growth and improvement during all studies, which would create conditions to improve the content of the study program at all stages of the teaching/learning process.

Funding: This research received no external funding.

Conflicts of Interest: The author declares no conflict of interest. 


\section{References}

1. Education 2030. Incheon Declaration and Framework for Action. Towards Inclusive and Equitable Quality Education and Lifelong Learning for All. Paris, UNESCO2016. Available online: http:/ /www.uis.unesco. org/Education/Documents/incheon-framework-for-action-en.pdf (accessed on 16 October 2018).

2. Education Transforms Lives. UNESCO (2017). Paris. Available online: http://unesdoc.unesco.org/images/ 0024/002472/247234e.pdf (accessed on 16 October 2018).

3. Education for Sustainable Development Goals Learning Objectives, 2017. United Nations Educational, Scientific and Cultural Organization. Available online: http:/ / unesdoc.unesco.org/images/0024/002474/ 247444e.pdf (accessed on 16 October 2018).

4. The Competences in Education for Sustainable Development. Learning for the future: Competences in Education for Sustainable Development United Nations Economic Commission for Europe (UNECE) Steering Committee on Education for Sustainable Development. 2012. Available online: https:// www.unece.org/fileadmin/DAM/env/esd/ESD_Publications/Competences_Publication.pdf (accessed on 26 November 2018).

5. Rogers, R. Reflection in Higher Education: A Concept Analysis. Innov. Higher Educ. 2001, 26, 37-57. [CrossRef]

6. Van Velzen, J.H. Are Students Intentionally Using Self-reflection to Improve how they Learn? Reflective Pract. 2015, 16, 522-533. [CrossRef]

7. Ash, S.; Clayton, P.H. Generating, Deepening, and Documenting Learning: The Power of Critical Reflection in Applied Learning. J. Appl. Learn. Higher Educ. 2009, 1, 25-48.

8. Ryan, M. The Pedagogical Balancing Act: Teaching Reflection in Higher Education. Teach. Higher Educ. 2013, 18, 144-155. [CrossRef]

9. McSweeney, J.M. Reflective Teaching and Learning: Why We Should Make Time to Think. Teaching Innovation Projects 2014, 4. Available online: http://ir.lib.uwo.ca/tips/vol4/iss2/7 (accessed on 20 September 2018).

10. Wong, A.C.K. Considering Reflection from the Student Perspective in Higher Education. SAGE Open. 2016. Available online: http://journals.sagepub.com/doi/10.1177/2158244016638706 (accessed on 26 October 2018).

11. Korthagen, F.A.J.; Vasalos, A. Levels in Reflection: Core Reflection as a Means to Enhance Professional Growth. Teach. Teach. Theory Pract. 2005, 11, 47-71. [CrossRef]

12. Pareja, R.N.; Margalef, L. Learning from Dilemmas: Teacher Professional Development through Collaborative Action and Reflection. Teach. Teach. 2013, 19, 18-32. [CrossRef]

13. Mathew, P.; Mathew, P.; Peechattu, P.J. Reflective Practices: A Means to Teacher Development. Asia Pac. J. Contemp. Educ. Commun. Technol. (APJCECT) 2017, 3, 126-131.

14. Special Education and Speech Therapy. 2018. Available online: https://www.aikos.smm.lt/registrai/ studiju-programos/_layouts/15/asw.aikos.registersearch/objectformresult.aspx?o=prog\&f=prog\&key= 4148\&pt=of (accessed on 19 December 2018).

15. Dèl Specialiosios Pedagoginès Pagalbos Asmeniui Iki 21 Metu Teikimo Ir Kvalifikaciniu Reikalavimu Nustatymo Šios Pagalbos Teikejams Tvarkos Aprašo Patvirtinimo. 2011. Available online: https: / e-seimas. lrs.lt/portal/legalAct/lt/TAD/TAIS.403927/qJrWBSSBCu (accessed on 19 December 2018).

16. Kirch, S.; Bargerhuff, M.; Cowan, H.; Wheatly, M. Reflections of Educators in Pursuit of Inclusive Science Classrooms. J. Sci. Teach. Educ. 2007, 18, 663-692. [CrossRef]

17. Welch, M.; James, R. An Investigation on the Impact of a Guided Reflection Technique in Service-Learning Courses to Prepare Special Educators. Teach. Educ. Spec. Educ. 2007, 30, 276-285. [CrossRef]

18. Beacham, N.; Rouse, M. Student Teachers' Attitudes and Beliefs about Inclusion and Inclusive Practice. J. Res. Spec. Educ. Needs 2011, 12, 3-11. [CrossRef]

19. Causarano, A. Becoming a Special Education Teacher: Journey or Maze? Reflective Pract. Int. Multidiscip. Perspect. 2011, 12, 547-556. [CrossRef]

20. Wlodarczyk, K.; Somma, M.; Bennett, S.; Gallagher, T.L. Moving Toward Inclusion: Inclusion Coaches' Reflections and Discussions in Supporting Educators in Practice. Except. Educ. Int. 2015, 25, 55-73. Available online: http:/ / ir.lib.uwo.ca/eei/vol25/iss3/4 (accessed on 26 November 2018). 
21. Fisher, T.; Somerton, J. Reflection on Action: The Process of Helping Social Work Students to Develop their Use of Theory in Practice. Soc. Work Educ. 2000, 19, 387-401. [CrossRef]

22. Mcilroy, D.; Todd, V.; Palmer-Conn, S.; Poole, K. Students' Self-Reflections on their Personality Scores Applied to the Processes of Learning and Achievement. Psychol. Learn. Teach. 2016, 15, 351-369. [CrossRef]

23. Wang, H.H.; Chen, H.T.; Lin, H.S.; Hong, Z.R. The Effects of College Students' Positive Thinking, Learning Motivation and Self-regulation through a Self-reflection Intervention in Taiwan. Higher Educ. Res. Dev. 2017, 36, 201-216. [CrossRef]

24. Cady, J.; Distad, L.; Germundsen, R. Reflective Practice Groups in Teacher Induction: Building Professional Community via Experiential Knowledge. Education 1998, 118, 459-470.

25. Bulpitt, J.; Martin, P.J. Learning about Reflection from the Student. Act. Learn. Higher Educ. 2005, 6, $207-217$. [CrossRef]

26. Tsang, N.M. Reflection as dialogue. Br. J. Soc. Work 2007, 37, 681-694. [CrossRef]

27. Ying, X.; Ke, F.; Sharma, P. The Effect of Peer Feedback for Blogging on College Students' Reflective Learning Processes. Internet Higher Educ. 2008, 11, 18-25.

28. Bouillet, D. Some Aspects of Collaboration in Inclusive Education-Teachers' Experiences. CEPS J. 2013, 3, 93-117.

29. Kaendler, C.; Wiedmann, M.; Rummel, N.; Spada, H. Teacher Competencies for the Implementation of Collaborative Learning in the Classroom: A Framework and Research Review. Educ. Psychol. Rev. 2014, 27, 505-536. [CrossRef]

30. Ha Le, J.J.; Wubbels, T. Collaborative Learning Practices: Teacher and Student Perceived Obstacles to Effective Student Collaboration. Camb. J. Educ. 2018, 48, 103-122. [CrossRef]

31. Hilden, S.; Tikkamäki, K. Reflective Practice as a Fuel for Organizational Learning. Adm. Sci. 2013, 3, 76-95. [CrossRef]

32. Peltier, J.; Hay, A.; Drago, W. The Reflective Learning Continuum: Reflecting on Reflection. J. Market. Educ. 2005, 27, 250-263. [CrossRef]

33. Nascimento, L.C.N.; Souza, T.V.; Oliveira, I.C.S.; Moraes, J.R.M.M.; Aguiar, R.C.B.; Silva, L.F. Theoretical Saturation in Qualitative Research: An Experience Report in Interview with Schoolchildren. Rev. Bras. Enferm. 2018, 71, 228-233. [CrossRef] [PubMed]

34. Saunders, B.; Sim, J.; Kingstone, T.; Baker, S.; Waterfield, J.; Bartlam, B.; Burroughs, H.; Jinks, C. Saturation in Qualitative Research: Exploring its Conceptualization and Operationalization. Qual. Quant. 2018, 52, 1893-1907. [CrossRef] [PubMed]

35. Moussa-Inaty, J. Reflective Writing through the Use of Guiding Questions. Int. J. Teach. Learn. Higher Educ. 2015, 27, 104-113.

36. Gibson, A.; Kitto, K.; Bruza, P. Towards the Discovery of Learner Metacognition from Reflective Writing. J. Learn. Anal. 2016, 3, 22-36. [CrossRef]

37. Shum, S.B.; Sándor, Á.; Goldsmith, R.; Bass, R.; McWilliams, M. Towards reflective writing analytics: Rationale, Methodology and Preliminary Results. J. Learn. Anal. 2017, 4, 58-84. [CrossRef]

38. Moon, J. Learning Journals. A Handbook for Academics, Students and Professional Development; Kogan Page: London, UK, 1999.

39. Hiemstra, R. Uses and Benefits of Journal Writing. Promoting Journal Writing in Adult Education. New Dir. Adult Contin. Educ. 2001, 90,19-26. [CrossRef]

40. Hoban, G. Using a Reflective Framework to Study Teaching-Learning Relationships. Reflective Pract. 2000, 1 , 165-182. [CrossRef]

41. King, T. Development of Student Skills in Reflective Writing. Available online: https://nursingmidwifery.tcd.ie/assets / director-staff-edu-dev/pdf/Development-of-Student-Skills-in-ReflectiveWriting-TerryKing.pdf (accessed on 15 September 2018).

42. Thorpe, K. Reflective Learning Journals: From Concept to Practice. Reflective Pract. 2004, 5, 327-343. [CrossRef]

43. Lindseth, A.; Norberg, A. A Phenomenological Hermeneutical Method for Researching Lived Experience. Scand. J. Caring Sci. 2004, 18, 145-153. [CrossRef] [PubMed]

44. Yip, K. Self-reflection in Reflective Practice: A Note of Caution. Br. J. Soc. Work 2006, 36, 777-788. [CrossRef]

45. Seibert, K.; Daudelin, W. The Role of Reflection in Managerial Learning: Theory, Research, and Practice; Quorum: Westport, CT, USA, 1999. 
46. Korthagen, F.; Loughran, J.; Lunenberg, M. Teaching Teachers. Studies into the Expertise of Teacher Educators. Teach. Teach. Educ. 2005, 21, 109-115. [CrossRef]

47. Swennen, A.; Klink, M. Becoming a Teacher Educator: Theory and Practice for Teacher Educators; Springer: Heidelberg, Germany, 2009.

48. Flores, M.A. Practice, Theory and Research in Initial Teacher Education. Eur. J. Teach. Educ. 2017, 40, $287-290$. [CrossRef]

49. Haverback, H.R.; Parault, S.J. Pre-service Reading Teacher Efficacy and Tutoring: A Review. Educ. Psychol. Rev. 2008, 20, 237-255. [CrossRef]

50. Eleyan, D.; Eleyan, A. Coaching, Tutoring and Mentoring in the Higher Education as a Solution to Retain Students in their Major and Help Them Achieve Success. In Proceedings of the International Arab Conference on Quality Assurance in Higher Education (IACQA), Amman, Jordan, 10-12 May 2011.

51. Foong, L.Y.Y.; Nor, M.B.N.; Nolan, A. The Influence of Practicum Supervisors' Facilitation Styles on Student Teachers' Reflective Thinking during Collective Reflection. Reflective Pract. Int. Multidiscip. Perspect. 2018, 19, 225-242. [CrossRef]

52. Stokking, K.; Leenders, L.; Van Tartwijk, J.; Van Tartwijk, J. From Student to Teacher: Reducing Practice Shock and Early Dropout in the Teaching Profession. Eur. J. Teach. Educ. 2003, 26, 329-350. [CrossRef]

53. Cohen, L.; Manion, L.; Morrison, K. A Guide to Teaching Practice; Routledge: London, UK; New York, NY, USA, 2004.

54. Kiggundu, E.; Nayimuli, S. Teaching Practice: A Make or Break Phase for Student Teachers. South Afr. J. Educ. 2009, 29, 345-358.

55. Sariçoban, A. Problems encountered by student-teachers during their practicum studies. Procedia Soc. Behav. Sci. 2010, 2, 707-711. [CrossRef]

56. Chang-Kredl, S.; Kingsley, S. Identity Expectations in Early Childhood Teacher Education: Pre-service Teachers' Memories of Prior Experiences and Reasons for Entry into the Profession. Teach. Teach. Educ. 2014, 43, 27-36. [CrossRef]

57. Koross, R. The Student Teachers' Experiences during Teaching Practice and Its Impact on their Perception of the Teaching Profession. IRA Int. J. Educ. Multidiscip. Stud. 2016, 5, 76-85. [CrossRef]

58. Dempsey, M.; Halton, C.; Murphy, M. Reflective Learning in Social Work Education: Scaffolding the Process. Soc. Work Educ. 2001, 20, 631-641. [CrossRef]

59. Brockbank, A.; McGill, I.; Beech, N. Reflective Learning in Practice; Gower Publishing: Burlington, NJ, USA, 2002.

60. Brownell, M.; Ross, D.; Colón, E.; McCallum, C. Critical Features of Special Education Teacher Preparation: A Comparison with General Teacher Education. J. Spec. Educ. 2005, 38, 242-252. [CrossRef]

61. McGlynn-Stewart, M. From Student to Beginning Teacher: Learning Strengths and Teaching Challenges. Cogent Educ. 2015, 2, 1-18. Available online: https:/ / www.cogentoa.com/article/10.1080/2331186X.2015. 1053182.pdf (accessed on 20 September 2018). [CrossRef] 